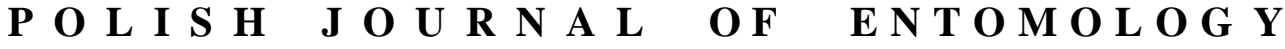

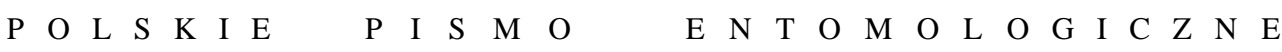

VOL. 86: 79-90

Lublin

31 March 2017

DOI: $10.1515 /$ pjen-2017-0006

\section{The role of selected plant metabolites in host plant choice by caterpillars of Acrobasis advenella (ZINCKEN, 1818) (Lepidoptera, Pyralidae)}

\section{EDYTA GÓRSKA-DrABIK* , KLAUdia MAGIEROWICZ}

Department of Entomology, Faculty of Horticulture and Landscape Architecture, University of Life Sciences in Lublin, Leszczyńskiego 7, 20-069 Lublin, Poland

\begin{abstract}
Acrobasis advenella is an oligophagous species feeding on plants of the Rosaceae family. The differences in concentrations of host plant quality components, above all primary metabolites and the presence or absence of secondary metabolites, directly affects herbivore growth and development. The objectives of this research were to determine the food preferences of $1^{\text {st }}$ instar larvae according to the chemical composition of host plants. The highest acceptance of rowan in the free choice test by $1^{\text {st }}$ instar larvae, as compared to hawthorn and black chokeberry, is positively influenced by the high content of total sugars and phenolic acids. The conclusion to be drawn from the results is that the differences in food choice by $1^{\text {st }}$ instar larvae feeding on fruits could have been due to the different chemical compositions of the fruit.
\end{abstract}

KEY WORDS: $\mathrm{L}_{1}$ larvae, plant - insect interaction, sugars, secondary metabolites, feeding.

\section{INTRODUCTION}

Acrobasis advenella (ZINCKEN, 1818) (Lepidoptera, Pyralidae) is an oligophagous species feeding on plants of the Rosaceae family, mainly the genera Crataegus L. and Sorbus L. (GOATER 1986, PALM 1986, SLAMKA 1997). The presence of this species on black chokeberry Aronia melanocarpa (MICHX.) ELLIOTT was confirmed for the first time in

*Corresponding author: edyta.drabik@up.lublin.pl 
south-eastern Poland in 2004 (GÓRSKA-DRABIK 2009). These plants are characterized by a high content of active compounds, especially phenolic compounds (HUKKANEN et al. 2006, WAWER 2010, ERCISLI et al. 2015).

The adult flight season lasts for about a month, starting in late June and continuing until the first days of August. During this time, females of Acrobasis advenella lay their eggs in the remnants of the calyx on immature fruits. When the larvae hatch, they bore into the fruits, making shallow corridors. The following year, after wintering, the caterpillars live on the developing flower buds, where they usually feed individually. Damaged flower buds may decrease yield, while feeding inside fruits causes a deterioration in their quality. Although the species is commonly present in native host plants, i.e. rowan Sorbus aucuparia L. and hawthorn Crataegus sp., it sometimes occurs on a large scale in chokeberry plantations. At present, Acrobasis advenella is considered a pest of the highest economic significance in such plantations. This is not only due to its feeding preferences (GÓRSKA-DRABIK 2013, 2014); its occurrence also depends on the presence of host plants. For preference, females lay their eggs on host plants that offer the best chance of larval development, but they will also accept plant species that are less appropriate when the preferred host is absent (AWMACK \& LEATHER 2002). Chokeberry is a minor crop in Poland (ca $6000 \mathrm{ha}$ ). Nonetheless, besides the small plantations that make up the majority, there are also plantations several tens and even several hundred hectares in area. These provide larvae of Acrobasis advenella with sufficient food, thereby ensuring the species' reproductive success.

The chemical composition of plants determines the relationship between insects and their host plants. Different chemical factors directing insects towards particular plants include those that satisfy the insect's demand for nutrients, the basic components of the diet and an important source of metabolic energy necessary for life processes (SEMPRUCH 2010). For many insects, sugar is the main factor determining a plant's acceptability, whereas secondary metabolites, being "specific plant substances", have an important effect on a plant's defence mechanisms against insect herbivores. The choice of host plant by such a herbivore is thus governed by these substances: some have a negative effect, acting in a deterrent, toxic or inhibitory manner, while others, usually in low concentrations, function as attractants (LESZCZYŃSKI 2010, OSZMIAŃSKI et al. 2015). How effective these compounds are in repelling or attracting insects depends on their concentrations in the host plant tissues. The differences in concentrations, above all of primary metabolites, and the presence or absence of secondary metabolites, directly affects a herbivore's growth and development, fecundity and insect reproductive strategies (AWMACK \& LEATHER 2002, SchoONHOVEN et al. 2005, MALINOWSKI 2008, SEMPRUCH 2010). However, the mechanisms of secondary metabolite activities towards herbivores are usually very complex and the narrow spectrum of activity of specific allelochemicals requires 
interactions between particular plant species and herbivores to be analysed.

The aim of this study was to assess the food preferences of $1^{\text {st }}$ instar larvae of Acrobasis advenella in the context of the chemical composition of the host plants - rowan, hawthorn and black chokeberry.

\section{MATERIALS AND METHODS}

\section{Larval host-plant choice in laboratory conditions}

In order to obtain the insect material, the oldest (about 10-12 mm) larvae of Acrobasis advenella feeding in inflorescences were collected from a black chokeberry (Aronia melanocarpa) plantation. They were then further reared in the laboratory. The larvae were kept separately in Petri dishes and fed on chokeberry leaves. After a few days, soil was added to ensure the best conditions for pupation. After eclosion, the adults were sexed, then paired off. The moths were fed with a $20 \%$ solution of honey. The eggs laid each day were removed with the fruit and placed in separate containers. Embryonic development was observed every day and the colour change of the eggs from yellow-green to light orange noted. Just before hatching, the eggs became white and transparent. Only eggs $(n=50)$ containing embryos with a black head capsule were used for the actual experiment. The freshly-hatched larvae were offered fruits of all three host plants (Aronia melanocarpa black chokeberry, Crataegus monogyna JACQ. - hawthorn, Sorbus aucuparia - rowan) in a free choice test. The tests were conducted in plastic insect boxes measuring $25 \times 15 \mathrm{~cm}$. Ten Acrobasis advenella eggs were placed at the bottom centre of each box. One infructescence, consisting of 10 individual fruits of rowan, hawthorn and black chokeberry, was placed at a distance of $4 \mathrm{~cm}$ from the eggs. The infructescences were inserted into floral foam to keep them fresh for as long as possible. The rearings were established about one or two days before the expected hatching date. They were checked every day and the numbers of larvae feeding on each species of fruit noted. Fruits -3 of chokeberry and 1 of hawthorn - with surface pitting, evidence of attempts by larvae to bore into them, were omitted from the analysis. The test was evaluated 24 hours after the last larvae had hatched. The experiment was conducted in the laboratory $\left(22^{\circ} \mathrm{C}, 70 \pm 5 \%\right.$ and $\mathrm{L}: \mathrm{D}=16: 8$ photoperiod), the conditions being the same for all five replicates.

\section{Analysis of primary and secondary metabolites in host plants}

The material for chemical analysis consisted of fresh, immature fruits of rowan, hawthorn and black chokeberry collected during the initial feeding period of $1^{\text {st }}$ instar larvae. The total sugar content was assayed using titration by the Schoorl-Luff method after acid hydrolysis to reduce monosaccharides (CHARŁAMPOWICZ 1966). The contents of 
flavonoids and anthocyanins were analysed by FP VIII spectrophotometry (2009) and the methods of MiŁKOWSKA \& STRZELECKA (1995). The content of anthocyanins was measured at wavelength $535 \mathrm{~nm}$, while flavonoids at $425 \mathrm{~nm}$. The percentage of flavonoids was calculated for quercetin. The phenolic acid content was analysed spectrophotometrically according to Arnova (FP VIII, 2009). The percentage of phenolic acids was calculated for caffeic acid. The data obtained from the chemical analyses of the fruits had earlier been used for analysing the preferences of Acrobasis advenella females during oviposition (GÓRSKA-DRABIK 2013).

\section{Statistical analysis}

The differences between the means for the variables were determined by ANOVA, assuming normality of distribution and homogeneity of variance. The significance of the differences between the means was tested with Tukey's Honestly Significant Difference test (HSD) at the significance level of $\mathrm{P}=0.01$.

\section{RESULTS}

$82 \%(n=41)$ of larvae fed in the fruits. The larvae usually occur individually. Only in one rowan fruit were four larvae found. Most of the caterpillars $(64.2 \%)$ chose rowan fruits immediately after hatching. The lowest number $(3.6 \%)$ of $1^{\text {st }}$ instar larvae was noted in hawthorn fruit (Fig.1).

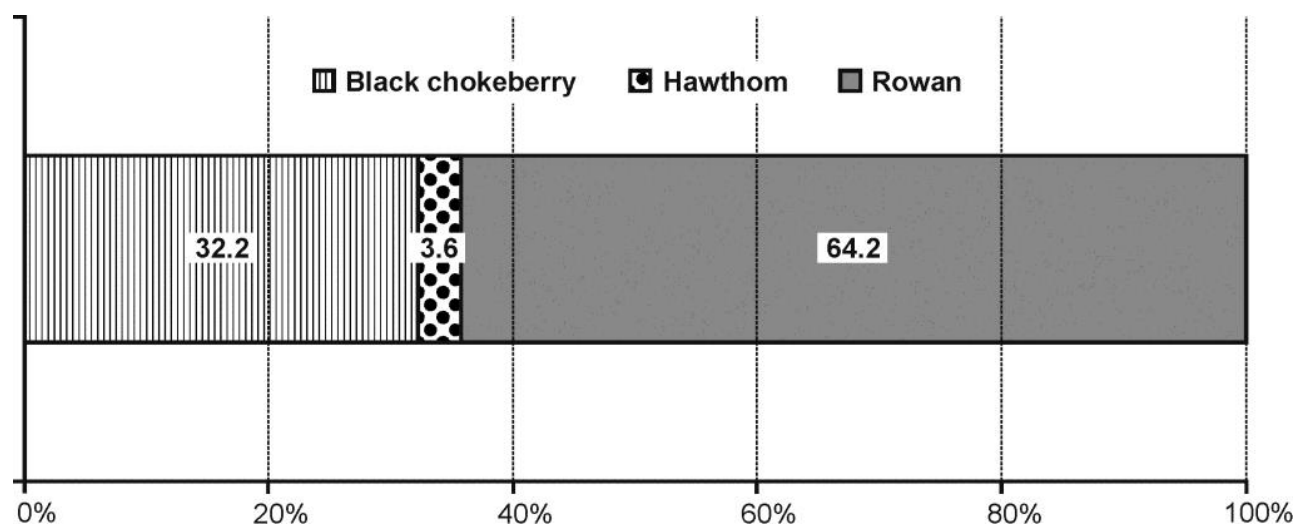

Fig. 1. Mean percentage of $1^{\text {st }}$ instar larvae of Acrobasis advenella feeding in fruits of three plant species. 


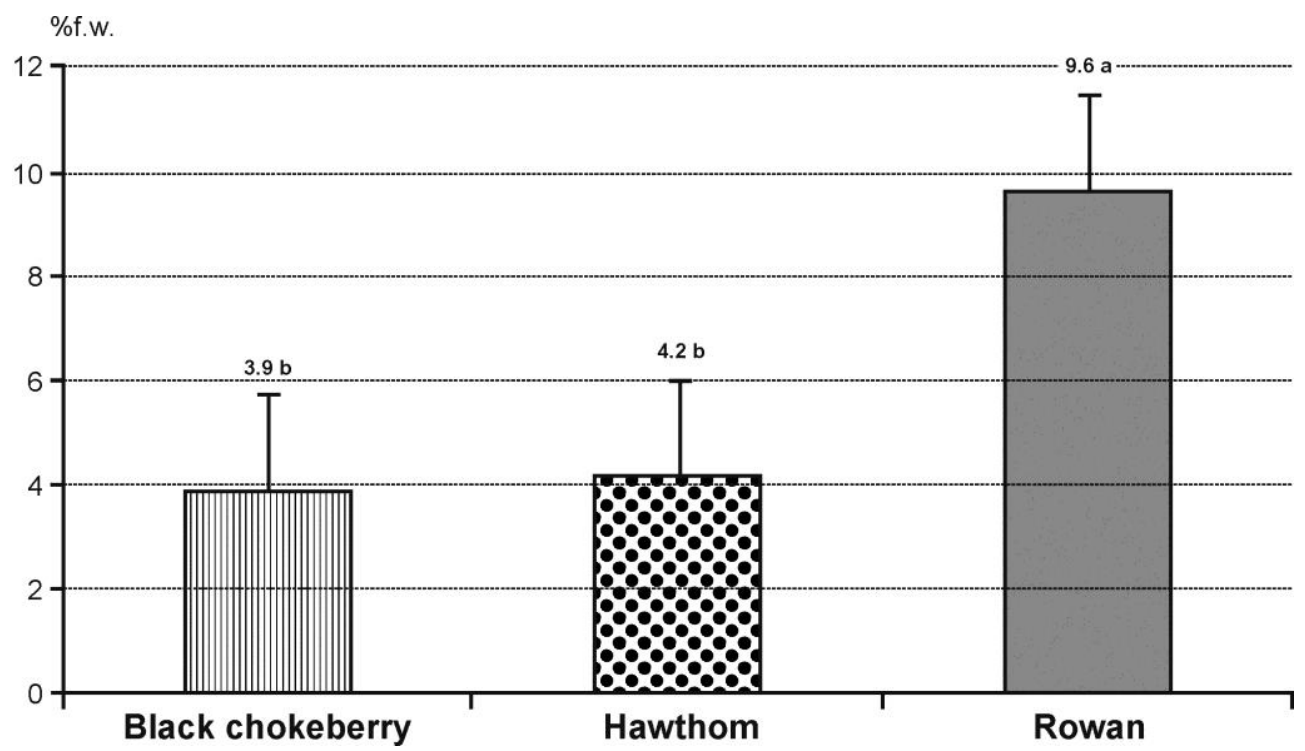

Fig. 2. Mean content of total sugars (\% f.w.) in fruits of three plant species. Values denoted by various letters differ significantly at $\mathrm{P} \leq 0.01$ (Tukey's HSD test).

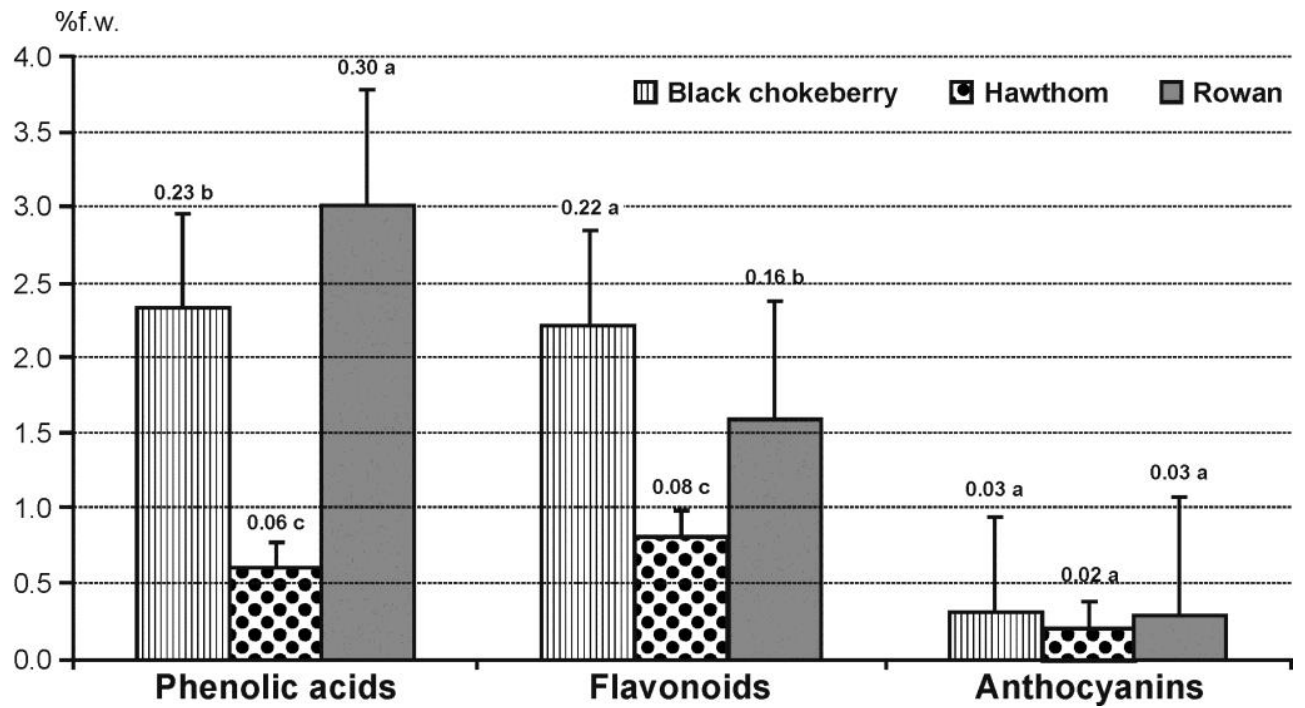

Fig. 3. Fig. 3. Mean content of phenolic acids, flavonoids (\% f.w.) and anthocyanins (g. $100 \mathrm{~g}^{-1}$ f.w.) in fruits of three plant species. Values for compounds denoted by various letters differ statistically significantly at $\mathrm{P} \leq 0.01$ (Tukey's HSD test). 
Chemical analysis of the three species of fruits showed that they differed significantly in their contents of sugars, phenolic acids and flavonoids (Fig. 2, 3), but that their anthocyanin contents were similar $\left(0.02-0.03 \mathrm{~g} \cdot 100 \mathrm{~g}^{-1}\right.$ of FW).

The mean content of total sugars in rowan fruits was the highest (Fig. 2) at $9.6 \%$, a value about 2.5 times higher than that of the black chokeberry and hawthorn fruits. The rowan fruits also had the highest content of phenolic acids $-0.3 \%$ of the fresh weight which was almost 5 times higher in comparison to hawthorn and about $25 \%$ higher than the content in black chokeberry fruits (Fig. 3).

The flavonoid content was the highest in black chokeberry fruits $(0.22 \%$ of fresh weight): they contained 2.5 times more of these compounds than hawthorn and 1.5 times more than rowan (Fig. 2).

Correlation analysis indicated a positive, quite strong relationship between the number of larvae feeding in the fruits and the concentrations of sugars $(\mathrm{r}=0.746168 ; \mathrm{p}=0.020947)$ and phenolic acids $(\mathrm{r}=0.746788 \mathrm{p}=0.020782)$.

\section{DISCUSSION}

When selecting host plants, herbivores secrete saliva and taste tissues by biting or pricking them. Responding to the chemical compounds contained in the surface tissues of plants, they determine whether or not to remain on this host and continue feeding on it. These compounds are mainly plant nutrients and allelocompounds (THOMPSON \& PELLMYR 1991, LESZCZYŃSKI 2010). Saccharides are among the most important nutrients for herbivores, and their concentrations in host tissues determine the taste of plants (HARBORNE \& Grayer 1993, Zou \& CATes 1994, Gantner 2007, Sempruch 2010, Golan 2013). Sugars are a carbon source and respiratory fuel for many species of insects. The content of these metabolites is also a significant factor stimulating feeding. Their low content is an important factor governing the lack of acceptance mechanism (SEMPRUCH 2010, GolAN $\&$ NAJDA 2011). This relationship has been documented in many herbivore species, such as Tetranychus urticae KocH. (Acari: Tetranychidae) (TOMCZYK 1998), Aphis fabae ScoP. (Sternorrhyncha: Aphidoidea) (CichOCKA \& LESZCZYŃSKI 2000), Phytoptus avellanae (Acari: Phytoseiidae) (GANTNER 2007) and Coccus hesperidum L. (Sternorrhyncha: Coccoidea) (GoLAN 2013).

The free choice test conducted as part of our research shows that $\mathrm{L}_{1}$ larvae chose to feed in rowan fruits twice as often as in black chokeberry and almost 18 times more often than in hawthorn. This might suggest that rowan fruits are the preferred food for these larvae. The biochemical results revealed considerable differences in saccharide concentrations in the fruits of each of these three plant species: they were twice as high in rowan fruits as in the 
other host plants on offer. Statistical analysis corroborated the significant part played by sugars, showing a high correlation between the numbers of $1^{\text {st }}$ instar larvae feeding in fruits and the concentration of total sugars. The results confirm earlier reports that comprehensively documented the role of sugars as feeding stimulants. The earlier research of one of the authors (AGD) also indicated the significant part played by these compounds in egg laying in Acrobasis advenella females (GÓRSKA-DRABIK 2013). The present research has shown that ovipositing females preferred fruits of Sorbus aucuparia, which contained the highest concentration of total sugars. In the context of free choice tests of host plant by females, and the present results of the free choice tests by $1^{\text {st }}$ instar larvae, sugar content appears to be an important factor determining host choice by Acrobasis advenella in both cases.

Although our research demonstrated a relationship between sugar content and the infestation of individual plant species by $1^{\text {st }}$ instar larvae, the acceptance of a host appears to depend not only on the sugar content but also on the level of secondary metabolites in host plant tissues. Secondary metabolites are among the phytochemicals that are the most involved in protecting plants against herbivores, with phenolic compounds being mentioned the most often. They are concentrated mainly in the peripheral vacuoles of plant tissues, which is why they play such an important role in interactions between plants and insects with chewing mouthparts. Phenolic compounds synthesized via the shikimate pathway are among the most active allelochemicals of plants (LESZCZYŃSKI 2001, RATTAN 2010).

Literature data suggest that phenolic acids could be a barrier to herbivores. Particular attention has been paid to their deterrent, or even toxic activity (SIMMONDS 2003, OSZMIAŃSKI et al. 2015). Phenolic acids are considered to decrease the activity of numerous enzymes, which leads to a decreased nutrient absorption. A high concentration of these compounds reduces fertility and the congenital growth rate of a population (BI et al. 1997, LATTANZIO et al. 2006); this has been confirmed in different studies. CZERNIEWICZ et al. (2011) showed that aphid populations increased rapidly on plants with low contents of phenolic compounds. A negative relationship between a high phenolic compound concentration and larval development has also been demonstrated in many lepidopteran species (FELTON et al. 1992, HORWATH \& STAMP 1993, STAMP \& YANG 1996, GANTNER et al. 2012). However, some phenolics are known to stimulate feeding and the growth of certain insect species (BERNAYS \& WOODHEAD 1982).

Flavonoids protect plants against abiotic and biotic stresses (SAVIRANTA et al. 2010), but in interactions with herbivores the parts they play may be diametrically different (HARBORNE \& GRAYER 1993). This has been confirmed in research into the effect of specific flavonoids on different species of beetles (Chrysomelidae) and moths from different families (Crambidae, Erebidae, Lasiocampidae). Flavonoids were found to stimulate the activity of Plagiodera versicolora (LAICHARING) beetles, but in high 
concentrations they tended to inhibit feeding activity in Phaedon brassicae (BALY) and Oulema oryzae (KuWAYAMA) (MATSUdA 1978). Studies done on different species of Lepidoptera (Ostrinia nubilalis HBN., Lymantria dispar L. and Malacosoma disstria HÜB.) showed that those compounds inhibited larval feeding and development (ABOU-ZAID et al. 1993, BENINGER \& ABOU-ZAID 1997, ABOU-ZAID et al. 2000). In contrast, the research of GANTNER (2007) and GANTNER et al. (2012) showed that flavonoids acted as attractants towards eriophyoids, aphids and the caterpillars of leafroller moths (Tortricidae). Similar results were obtained by BURGHARDT et al. (2000) and LATTANZIO et al. (2006), who noted the stimulatory activity of flavonoids towards insects. In a free choice test, however, Golan (2013) showed that motile forms of the polyphagous species Coccus hesperidum preferred the host with the highest flavonoid content (Ficus benjamina L.), although further development on this host species was the least advantageous with, among other things, the highest death rate of larval stages.

Rowan and black chokeberry fruits contain relatively high concentrations of both phenolic acids and flavonoids. However, our results show that even though rowan fruits contained the highest concentrations of phenolic acids of all the tested species, this did not decrease their attractiveness to $1^{\text {st }}$ instar larvae. This was additionally confirmed by correlation analysis.

We may conclude from our results that a relationship exists between the concentrations of secondary metabolites in the fruits of the species tested and the rate of infestation by $1^{\text {st }}$ instar larvae. This study has demonstrated that phenolic acids do not constitute a barrier against colonization by herbivores. The phenolic acid content was about 5 times lower in hawthorn fruits and 25\% lower in black chokeberry fruits than in rowan. The hawthorn fruits were attacked the least often by larvae during the free choice test. Similar results were obtained in the case of the flavonoid content. The concentration of those compounds in hawthorn fruits was a few times lower than in the fruits of the other species. One may assume that high levels of phenolic acids and flavonoids act as attractants to Acrobasis advenella $1^{\text {st }}$ instar larvae.

According to literature data, anthocyanins function mainly as visual signals to insects (HAMilton \& BRown 2001, SingH \& SAXENA 2004). GANTNER et al. (2012) documented the attractive nature of these compounds. On the other hand, HAMILTON \& BROWN (2001) and ARCHETTI et al. (2009) showed that they operate as repellents and informers of the host's 'low nutritional value'. Biochemical analysis of the fruits examined in this work showed their anthocyanin contents to be similar in all three species. We may thus infer that anthocyanins do not play an important role in the choice of a host as a food source by the $1^{\text {st }}$ instar larvae of Acrobasis advenella. 


\section{CONCLUSION}

The differences in food choice by $1^{\text {st }}$ instar larvae could have resulted from the different chemical compositions of the fruits offered. The high level of acceptance of rowan fruits by the larvae was probably due to the high content of sugars, total phenolic acids and flavonoids in them. Hawthorn fruits, the food least accepted by the larvae, had the lowest contents of these compounds. The results suggest that these compounds could have played an important role in the choice of food by Acrobasis advenella $1^{\text {st }}$ instar larvae.

On the basis of these results and an earlier study involving a free choice test of host plants by A. advenella females, the concentrations of the same compounds appear to be an important factor in both processes.

\section{FUNDING}

Funding. The study was financed from funds of the Ministry of Science and Higher Education in 2010-2013 as a research project (N 310308439).

\section{REFERENCES}

Abou-Zaid M.M., Beninger C.W., Arnason J.T., Nozzolillo C. 1993. The effect of one flavanone, two catechins and four flavonols on mortality and growth of the European corn borer (Ostrinia nubilalis HÜBNER). Biochemical Systematics and Ecology 21(4): 415-420.

Abou-Zaid M.M., Grant G.G., Helson B.V., Beninger C.W., Degroot P. 2000. Phenolics from deciduous leaves and coniferous needles as sources of novel control agents for lepidopteran forest pests. [in:] F. SHAHIDI, C.T. Ho (eds.). Phytochemicals and Phytopharmaceuticals. AOCS Press, Champaign, IL, 398-417.

Archetti M., Döring T.F., Hagen S.B., Hughes N.M., Leather S.R., Lee D.W., Lev-Yadun S., MANETAS Y., Ougham H.J., SChaberg P.G., ThOMAS H. 2009. Unravelling the evolution of autumn colours: an interdisciplinary approach. Trends in Ecology \& Evolution 24(3): 166-173.

AwMAck C.S., LeATHER S.R. 2002. Host plant quality and fecundity in herbivorous insects. Annual Review of Entomology 47: 817-844.

BENINGER C.W., ABou-Zaid M.M. 1997. Flavonol glycosides from four pine species that inhibit early instar gypsy moth (Lepidoptera: Lymantriidae) development. Biochemical Systematics and Ecology 25(6): 505-512.

BERNAYS E.A., WOODHEAD S. 1982. Plant phenols utilized as nutrients by a phytophagous insect. Science 216(4542): 201-203.

Bi J.L., Murphy J.B., Felton G.W. 1997. Antinutritive and oxidative components as mechanisms of induced resistance in cotton to Helicoverpa zea. Journal of Chemical Ecology 23(1): 97-117. 
Burghardt F., Knuttel H., Becker M., Fiedler K. 2000. Flavonoid wing pigments increase attractiveness of female common blue (Polyommatus icarus) butterflies to mate-searching males. Naturwissenschaften 87(7): 304-307.

CharŁampowicz Z. 1966. Analyses of fruit, vegetable, and mushroom products. WPLiZ, Warszawa, 115-120. (in Polish)

CichockA E., LeszCZYŃSKi B. 2000. The use of EPG Technique in assessing of susceptibility of the broad bean to black bean aphid (Aphis fabae SCOP.). Aphids and Other Homopterous Insects 7: 29-36.

CZerniewicz P., Leszczyński B., ChrZanowski G., Sempruch C., Sytykiewicz H. 2011. Effects of host plant phenolics on spring migration of bird cherry-oat aphid (Rhopalosiphum padi L.). Allelopathy Journal 27(2): 309-316.

ERcisli S., Yanar M., Sengul M., Yildiz H., Topdas E.F., Taskin T., Zengin Y., YilmaZ K.U. 2015. Physico-chemical and biological activity of hawthorn (Crataegus spp. L.) fruits in Turkey. Acta Scientiarum Polonorum Hortorum Cultus 14(1): 83-93.

Felton G.W., Donato K.K., Broadway R.M., DufFey S.S. 1992. Impact of oxidized plant phenolics on the nutritional quality of dietary protein to a noctuid herbivore, Spodoptera exigua. Journal of Insect Physiology 38(4): 277-285.

GANTNER M. 2007. The sources of resistance of chosen hazelnut cultivars (Corylus L.) on the filbert big bud mite (Phytoptus avellanae NAL.) and filbert aphid (Myzocallis coryli GoETZE). Akademia Rolnicza w Lublinie, Lublin. (in Polish)

GANTNER M., NAJDA A., JANIUK M. 2012. Attractiveness of highbush blueberry (Vaccinium corymbosum L.) cultivars to leafrollers depending on chosen secondary metabolites. Progress in Plant Protection 52(4): 820-825.

GoATER B. 1986. British Pyralid Moths. A Guide To Their Identification. Harley Books, Colchester.

GoLAN K. 2013. Interaction between host plants and Coccus hesperidum L. (Hemiptera; Sternorrhyncha; Coccidae). Uniwersytet Przyrodniczy w Lublinie, Lublin.

Golan K., NAJDA A. 2011. Differences in the sugar composition of the honeydew of polyphagous brown soft scale Coccus hesperidum (Hemiptera: Sternorrhyncha: Coccoidea) feeding on various host plants. European Journal of Entomology 108(4): 705-709.

GóRSKA-DRABIK E. 2009. Trachycera advenella (ZINCK.) (Lepidoptera, Pyralidae) - a new pest on black chokeberry (Aronia melanocarpa). Progress in Plant Protection 49(1): 531-534. (in Polish)

GÓRSKA-DRABIK E. 2013. Occurrence of Acrobasis advenella (ZINCK.) (Lepidoptera, Pyralidae, Phycitinae) on black chokeberry in Poland and its biochemical interaction with host plants. Uniwersytet Przyrodniczy w Lublinie, Lublin. (in Polish)

GóRSKA-DRABIK E. 2014. Acrobasis advenella to treat black chokeberry plantations [in:] Materiały $\mathrm{X}$ Międzynarodowej Konferencji Sadowniczej „Aktualności w produkcji owoców jagodowych i pestkowych", Kraśnik, 49-51.(in Polish)

Hamilton W.D., Brown S.P. 2001. Autumn tree colours as a handicap signal. Proceedings of the Royal Society B: Biological Sciences 268(1475): 1489-1493.

HARborne J.B., GRAYER R.J. 1993. Flavonoids and insects. [in:] J.B. HARbORNE (ed.). The flavonoids: advances in research since 1986. Chapman \& Hall, London, 559-618. 
HoRwath K.L., Stamp N.E. 1993. Use of dietary rutin to study molt initiation in Manduca sexta larvae. Journal of Insect Physiology 39(11): 987-1000.

Hukkanen A.T., Polonen S.S., Karenlampi S.O., Kokko H.I. 2006. Antioxidant capacity and phenolic content of sweet rowanberries. Journal of Agricultural and Food Chemistry 54(1): 112-119.

LatTanzio V., LatTAnZio V.M.T., CARDinali A. 2006. Role of phenolics in the resistance mechanisms of plants against fungal pathogens and insects. [in:] F. IMPERATO (ed.). Phytochemistry: Advances in Research. Research Signpost. Trivandrum, Kerala, 23-67.

LeSZCZYŃSKi B. 2001. Natural resistance of plants to pests. [in:] W. OlesZeK, K.GŁowniaK, B. LESZCZYŃSKI (eds.). Biochemical environmental effects. Akademia Medyczna, Lublin, 87-108. (in Polish)

LESZCZYŃSKI B. 2010. Selected problems of biochemistry and environmental toxicology. Wydawnictwo Akademii Podlaskiej, Siedlce. (in Polish)

MalinOwSKI H. 2008. Defensive mechanisms of woody plants against harmful insects. Progress in Plant Protection 48(1): 25-33. (in Polish)

MATSUDA K. 1978. Feeding stimulation of flavonoids for various leaf beetles (Chrysomelidae: Coleoptera). Applied Entomology and Zoology 13(3): 228-230.

MiŁKOWSKa K., STRZELECKa H., 1995. Flos Hibisci - methods for the identification and evaluation of raw material. Herba Polonica 41(1): 11-16. (in Polish)

OSZMiańSKi J., KOLNIAK-OSTEK J., BIERnAT A. 2015. The content of phenolic compounds in leaf tissues of Aesculus glabra and Aesculus parviflora WALT. Molecules 20(2): 2176-2189.

PALM E. 1986. Danish Wildlife Vol. 3. Pyralids of North Europe (Lepidoptera: Pyralidae). Fauna Bøger, Københawn. (in Danish)

Polish PhaRmacopoeia VII 2009. Polskie Towarzystwo Farmaceutyczne, Warszawa.

Polish Pharmacopoeia VIII 2009. Polskie Towarzystwo Farmaceutyczne, Warszawa.

RATTAN R.S. 2010. Mechanism of action of insecticidal secondary metabolites of plant origin. Crop Protection 29(9): 913-920.

SaviRnata N.M., Jukunen-TitTo R., OKSANEN E., KaRJalainen R.O. 2010. Leaf phenolic compounds in red clover (Trifolium pratense L.) induced by exposure to moderately elevated ozone. Environmental Pollution 158(2): 440-446.

SchoOnhoven L.M., LOON J.A., Dicke M. 2005. Insect-Plant Biology. Oxford University Press, Oxford.

SEMPRUCH C. 2010. Nitrogen compounds in interactions between plants and herbivorous insects. Kosmos 59(1-2): 199-209. (in Polish)

SIMMONDS M. 2003. Flavonoids-insect interactions: recent advances in our knowledge. Photochemistry 64(1): 21-30.

SingH A.K., SAXENA K.N. 2004. Attraction of larvae of the armyworm Spodoptera litura (Lepidoptera: Noctuidae) to coloured surfaces. European Journal of Entomology 101(4): 697-699.

SLAMKA F. 1997. Die Zünslerartigen (Pyraloidea) Mitteleuropas. F. Slamka, Bratislava.

STAMP N.E., YANG Y.L. 1996. Response of insect herbivores to multiple allelochemicals under different thermal regimes. Ecology 77(4): 1088-1102. 
TOMCZYK A. 1998. Content of some organic compounds in the leaves of cucumber in relation to its susceptibility to spider mites. Zeszyty Naukowe - Akademia Techniczno-Rolnicza im. Jana i Jędrzeja Śniadeckich w Bydgoszczy 214, Ochrona Środowiska 2: 115-120.

ThOMPSON J.N., PeLlmyr O. 1991. Evolution of oviposition behavior and host preference in Lepidoptera. Annual Review of Entomology 36: 65-89.

WAwer I. 2010. The Power of nature: Aronia melanocarpa. Mae's Health and Wellness LCC, Omaha, NE, USA.

Zou J.P., CATES R.G. 1994. Role of douglas fir (Pseudotsuga menziesii) carbohydrates in resistance to budworm (Choristoneura occidentalis). Journal of Chemical Ecology 20(2): 395-405.

Received: 9 December 2016

Accepted: 30 December 2016 